\title{
THE “OTHER SIDE” OF ARCHITECTURAL RECONSTRUCTION
}

\author{
PROFESSIONAL, SOCIAL AND POLITICAL QUESTIONS \\ IN ARCHITECTURAL RECONSTRUCTION BY THE EXAMPLE \\ OF OLD BRIDGE IN MOSTAR
}

\author{
MAJA TOSHIKJ'四 ÁKOS ZSEMBERY² \\ ${ }^{1} \mathrm{PhD}$ student. Department of History of Architecture and Monument Preservation, \\ BUTE II. 82, Mủegyetem rkp. 3, H-1111 Budapest, Hungary. E-mail: majatoshikj@gmail.com \\ ${ }^{2} \mathrm{PhD}$, assistant professor. Department of History of Architecture and Monument Preservation, \\ BUTE K II. 82, Müegyetem rkp. 3, H-1111 Budapest, Hungary. E-mail: zsembery@eptort.bme.hu
}

Focusing on architectural reconstructions after armed conflicts ${ }^{1}$ in the area of the former Yugoslav republics 2 , we would like to present the "other side" of the reconstruction by the example of the Old Bridge in Mostar; or rather, what is determinative in this special area of monumental preservation over the professional consideration: the social and political aspects. These aspects will be dealt with in more detail by examining the overall post-conflict reconstruction situation of cultural heritage in Bosnia and Herzegovina, involving diverse opinions from experts and international assistance. This article re-examines, among others, the prosperity of the recovery indicating an authenticity question, posed as: "how far can an authentic experience be recreated or conjured through the simulation of an absent original monument?"3

We evaluate the process and stages of the reconstruction of the Old Bridge in a spirit of "identical" restoration, by understanding its structure and rebuilding in identical shape and dimension, using original materials and construction techniques, based on archival documents. The judgement of the architectural reconstruction or rebuilding also depends on multiple aspects: the recognition and assertion of the hierarchy of values - material or physical, as well as intangible or immaterial. Delayed in the process, by nearly a decade due to the political and economic situation, it is important to evaluate several problems that occur, emphasizing in turn: the question of the original form, original spaces in the mirror of the history that formed in another way. This side raises ethical and moral questions as well.

The approach and judgement of the architectural reconstruction is also different in the republics of the former Yugoslavia after the recent armed conflict. Seeing the diverseness in the social and political background the question arises whether the new reconstruction is another layer in the "stratigraphy" of the monument or it is the lockup of the past?

Keywords: architectural reconstruction, Old Bridge, armed conflict, authenticity, cultural heritage

${ }^{\otimes}$ Corresponding author.

${ }^{1}$ In this article, special attention is given to the Bosnian War, during 1992-1995. For more in detail, see Kreimer et al. 2000. 21.

${ }^{2}$ The term "former Yugoslavia" and The Socialist Federal Republic of Yugoslavia (SFRY) is referring to the territory of federation consisting of six republics - Bosnia and Herzegovina, Croatia, Macedonia, Montenegro, Serbia (including the regions of Kosovo and Vojvodina, as autonomous provinces within Serbia) and Slovenia, lasting until the start of its dissolution in mid 1991 brought about by the Yugoslav Wars.

${ }^{3}$ Bold 2018. 4. 


\section{INTRODUCTION}

In general, the specific area of the architectural reconstruction in the former Yugoslav countries can be studied on different levels. The first one represents a wider vision of social/political and professional problems facing the Balkan region's inhabitancy by various ethnic and cultural groups. This aspect is based on an intensive and fundamental debate engaging intellectuals and experts, involving international assistance, such as the local population, the Money fund and UNESCO, in the role and importance of culture from early on in the recovery phrase, different prevention patterns, international policies, information on international aid for post-conflict reconstruction, legal acts and doctrinal texts. The second one is the response to the problems facing the authenticity and integrity of the reconstruction.

As we could see, the cultural heritage of the enemy has been seen as a target of deliberate attacks in reaching the goal of destroying "cultural symbols tied to belief, identity, power and empowerment [...] valued most" 4 and "monuments of historical and religious importance, libraries, and museums containing portable works of art - in other words, those places that are of high symbolic value and whose destruction is believed would cause the greatest despair"s. In such extreme situations, social reconstruction and eventual reconciliation of communities torn by war, actively include post-conflict reconstruction of cultural heritage in recovery strategies, as a key element in achieving the general stability, security and poverty, and a national, political and psychological necessity. However, architectural reconstruction is the most disputed side of the monumental preservation; it is well known that "heritage conservation professionals have traditionally been opposed to reconstruction because this approach can falsify history and create fictional places that never existed in that form" and moreover, "subsequent standards and guidelines have consistently expressed caution about reconstructing historic sites." Therefore, we can examine different hypothesis relating to recent reconstructions, evaluate monumental interventions and components of authenticity, and update the rule of contemporary reconstruction for the future.

In this context, we focus on a specific part of our research work: the methodological and experiential reconstruction of the Old Bridge in Mostar.

\section{THE OLD BRIDGE - A WAY OF RECONSTRUCTION}

\section{A BRIEF HISTORY}

A number of studies on the first settlements of present-day Mostar indicate that the city was founded around 1440. The Ottoman Empire conquered Mostar in 1468, as

${ }^{4}$ Barakat 2005. 28.

${ }^{5}$ Stanley-Price 2005. 4-5.

${ }^{6}$ Cameron 2017. 57. 


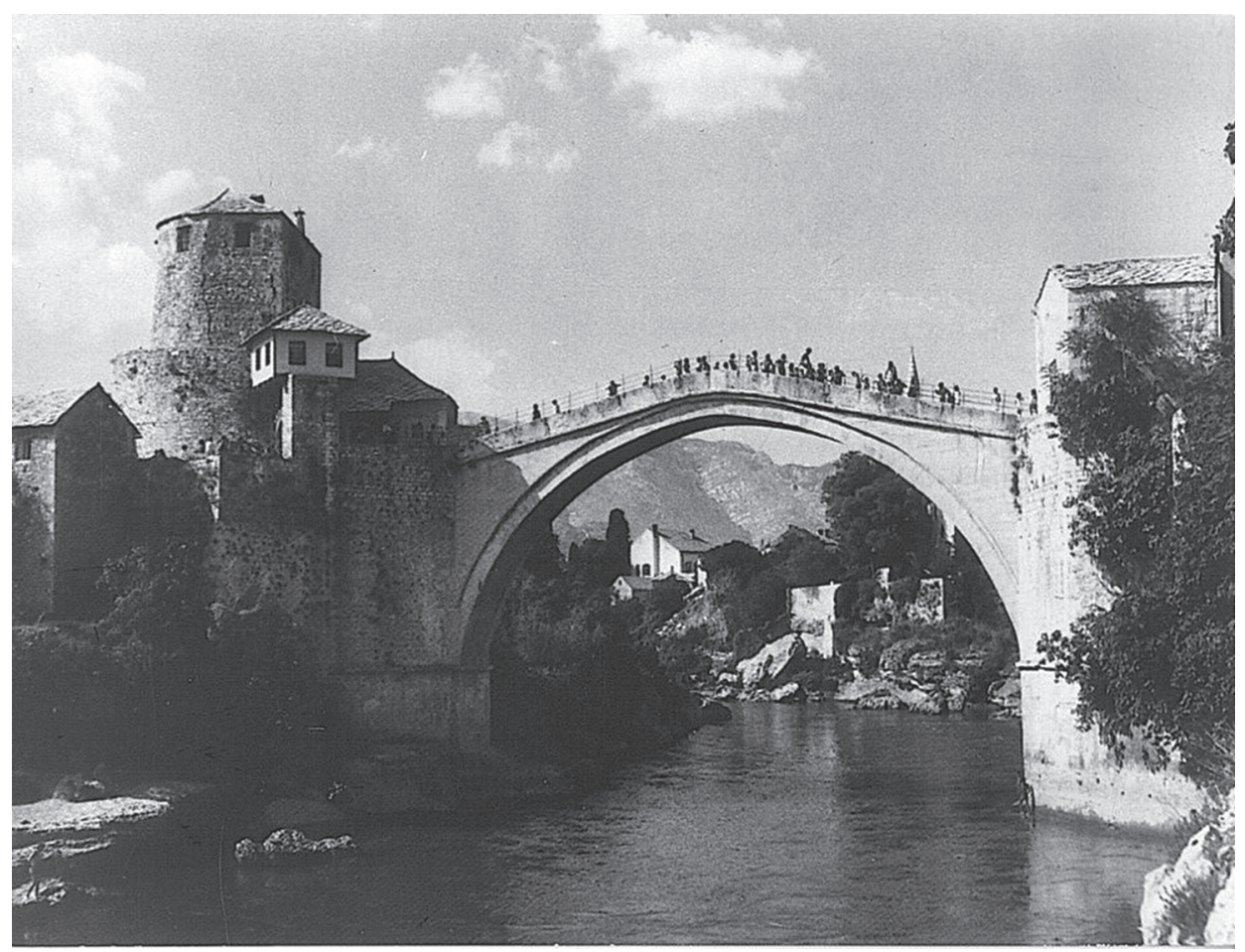

Figure 1. Old Bridge in the 1960's (after Roller 1992-1993. 318)

Sultan Suleiman the Magnificent made a request of building a new stone bridge, replacing the existing wooden bridge originating from 1444. The Old Bridge was built in 1566 by Hayruddin, who was a pupil of the greatest Ottoman architect Kodze Mimara Sinan. Another record from the Sarajevo National Museum indicates that the construction of the bridge started in $1557^{7}$ and lasted nine years until its completion. It is considered to be a symbol of the old city and a monumental stone bridge (Fig. 1). It is plausible that local citizens, carvers and masons from Dalmatia assisted in the construction work, by using local materials in accordance to the greatest work of the architect. ${ }^{8}$

${ }^{7}$ Significant differences in data were detected in the available records between chronological information regarding the beginning and the end of the bridge construction work. (Žderić-Radić-Kindij 2007; Čolak 2013; Colak 2016; Peković 2006; Popovac 2006; Popovac 2011; Orlando-Spinelli-Vignoli 2003.) For a general overview of Ottoman bridges in Bosnia and Herzegovina see Čelić-Mujezinović 1998.

${ }^{8}$ Žderić-Radić-Kindij 2007; Čolak 2013. 


\section{DEVASTATION}

After more than a year of constant Croatian military attacks as an imminent threat, in November 1993, the Old Bridge span construction was destroyed by shelling in the Bosnian War. What is known about the destruction of the bridge is largely based on some documentation from captured films, technical data and observations, as Hadzimuhamedovic ${ }^{9}$ reported: it "represented the beginning of a new era in the approach to heritage". Attracting much attention among the attacks on cultural property during a war, the old town of Mostar, especially the Old Bridge, have become an enquiry passed on through time, in search for the motive and demand for destruction of cultural property.

\section{LOCAL ROOTS AND "IMMATERIAL LOSS"}

The last two decades of the twentieth century in the SFRY have seen a renewed importance in the mobilization of different ethnic and religious groups throughout the countries under federation; followed by a multicultural coexistence and achievement of the desired and promised idea of "framing the common culture into state structures", regarding a main unifying factor in the establishment of SFRY such as a "common identity based on common language and shared traditions" ${ }^{10}$ The attempt of establishing a harmonious relation and containment of different ethnic communities by rebuilding many different religious buildings, was seen as massive politicization on a religious basis. However, in the period between 1992 and 1995, with the breakdown of the SFRY and declaration of independence in most of the states, Bosnia and Herzegovina as an ethnically diverse area was awakening and raising the national consciousness and the disregard of shared identity between the citizens. Correspondingly, the regulating territories were driven towards destroying and thoroughly defeating the other identities with a so-called, ethnical cleansing. At this extreme, two different forms of cultural identity are at risk of being damaged by the war, and according to Ascherson ${ }^{11}$, not only the social or anthropological identity, "social cohesion as a daily-life community bonded by living language and custom", but also on the collective identity, "the promotion of national unity by labeling treasured objects as a common national heritage or "our civilization" "12, referring to the mosques, monuments, libraries etcetera.

In search of comprehensive understanding of the motives for attacking cultural property and considering a broad range of armed conflicts, the analysis of J. Brosché et al. ${ }^{13}$ gave a general overview of the intention behind deliberate attacks on cultural

\footnotetext{
${ }^{9}$ Hadzimuhamedovic 2018. 22.

${ }^{10}$ Kostadinova 2013. 4.

${ }^{11}$ Ascherson 2005. 20.

${ }^{12}$ Op. cit. 20.

${ }^{13}$ Brosché et al. 2016. 248-260.
} 
property. Furthermore, they presented a typology ${ }^{14}$ by combining insights from a research on peace and conflict with findings from heritage studies. Comprehending the two principal identifiers of difference, religion and ethnicity, coupled with establishing superior power over the enemy, was a crucial part of the conflicts in former Yugoslavia and the reason behind attacking the cultural property. Henceforth this seems to be a reliable approach for designing policies in the prevention of such attacks or an estimation of the greatest point of the risk. In particular, certain studies suggested revealing the source of conflict, which involved the economic and ideological factors as well.

The cultural properties, such as mosques, churches and monasteries, in other words the main conveyors of collective memory and symbols of identity, have been a main target of systematic destruction on a large scale for military and political purposes and "may constitute a way to achieve a warring party's goal for the conflict". ${ }^{15}$ In Bosnia and Herzegovina, the prime reason of the wartime destruction of cultural heritage is a consequence of its usage as "a collateral ethnic cleansing tool and aimed to erase the collective memory of the peaceful coexistence between Serbs, Croats and Muslims". ${ }^{16}$

"In multi-ethnic communities (Bosnia and Herzegovina for instance), the presence of certain monuments can seem to affirm the right to space through their presence across the time. When they are knocked down - as when a mosque is blown up - the resulting fear and insecurity can be intense." 17 This seems to be somewhat related with the major conflict goal, and can be clearly recognized in gaining a legitimate right to a particular territory, and accordingly, "the destruction of the bridge was thus an attack on the idea of a future multi-ethnic nation". ${ }^{18}$ Therefore, "the reconstruction of cultural heritage is a highly political matter both on domestic and international levels" 19 in multi-ethnic and multi-religious societies, especially ones with piercing importance such as the Old Bridge, represent an opportunity to reintegrate in the community, affirming a cultural existence of a group and strengthening the national identity.

According to this view, the approach is based on the three dimensions of peace-building in the (post) complex emergencies of Southeastern Europe, which has been suggested as a reliable approach of strategies addressing "local roots of hostility, the specific degree of international commitment available to assist sustainable peace and the local capacities for change". ${ }^{20}$

\footnotetext{
${ }^{14}$ For a more general discussion on erasure of heritage see: Brosché et al. 2016. 248-260. The four clusters of motivations the researchers listed are: (i) conflict goals where cultural property is targeted because it constitutes a key issue in the conflict), (ii) military-strategic where cultural property is targeted in order to gain tactical benefits, (iii) signaling in which cultural property is targeted in order to illustrate commitment, and (iv) economic where cultural property is attacked in order to finance armed groups.

${ }^{15}$ Brosché et al. 2016. 251.

${ }^{16}$ Kostadinova 2013. 10.

${ }^{17}$ Ascherson 2005. 22.

${ }^{18}$ Brosché et al. 2016. 252.

${ }^{19}$ Teijgeler 2011. 90. Cited in Kostadinova 2013. 16.

${ }^{20}$ Doyle and Sambanis 2000. 779. Cited in Kostadinova 2013. 4.
} 
This strategy has been a commencement for the conception of a peace and social-building model in war-affected states, multi-ethnic societies in the region, including Bosnia and Herzegovina, among others. Accordingly, the starting point is finding the cause for destruction, which is of great importance for progressing to the final phase of rebirth and reconstruction. In this way, the reconstruction of the overall society after an armed conflict, is pivotal to the reconstruction of cultural heritage.

As it is well known, masonry bridges at that time had been extremely difficult and problematic to construct, so consequently, it has not a single design work, but a continual development throughout history. Its historical and monumental relevance in a diachronic sense ${ }^{21}$ its devastation and current presence of the reconstructed structure, allowed us to choose the Old Bridge as an exemplar to conceive a complete methodological study.

\section{THE “TWO SIDES” OF ARCHITECTURAL RECONSTRUCTION}

Every monumental intervention has double motivation. The role is not only the professional salvation of the architectural monument, but furthermore, giving back a lost piece of the cultural identity to the community. Along the history of monument preservation, these two claims influenced the ways of interventions in varying degrees. During the intervention, the objective and subjective criteria are different. Through professional criteria, with the background of research results, we bring in more objective verdicts than in the case of social criteria, where subjective verdicts always arise. Although in conservation of ruins the professional side is evidently stronger than the social one, in the rebuilding of demolished monuments, the social or political side will become conspicuous. That is why we can call it the "second side" of the reconstruction. Its effects on the professional interventions are far stronger nowadays than before.

Professional

(more objective less subjective) conservation

\author{
Social/Political \\ (more subjective less objective) \\ restauration \\ reconstruction
}

This social and/or political side is varicolored and elusive from a professional perspective. This can lead to solutions that in a professional sense are already over the admitted interventions of the monumental preservation, such as renewing, rehabilitation, transformation, utilization, etcetera.

The terminology of architectural reconstruction - toward the notion of conservation and restoration - is immature. It is a complicating factor in the evaluation and the diverse terminology of the European countries. Consequently, this type of inter-

\footnotetext{
${ }^{21}$ Historical significance of the structure from the early nature of establishment from the Ottoman era and the continuity in development of the historic core of Mostar.
} 
vention for decades was "disabled" in many countries, firstly because of the problematic approach towards the question of authenticity. After the Second World War's destruction, the "new principles" have grown stronger in Europe, as the period between the wars wasted away in the post-conflict rehabilitation and rebuilding. Through the Venice Charter ${ }^{22}$ and other international recommendations from the middle of the $20^{\text {th }}$ century, this reconstruction effort transformed and the large-scale rebuilding occurred all over. However, after the period of the great political changes in Eastern Europe, with a duration of three decades, this question seems to be recurrent. Notably, reconstructions of long-standing ruined monuments in Central and Eastern Europe ${ }^{23}$ have occurred or are in process, not only in regions that have endured the war.

Naturally, we have to make a distinction between the reconstruction in a short time after the disaster and the rebuilding of a monument that was in ruins for centuries. Namely because of this "time-factor" the relation between the intervention and its social, political and economical background is not the same. Although the new charters, as the Charter of Krakow or the Riga Charter ${ }^{24}$ try to make the difference with the terminology of "identity", we can see that it can raise the same problems as the terminology of "authenticity".

Other evaluations, especially historical, cultural, material, immaterial, etc., lead to discrepant practices in different countries. To emphasize, the practice of one is more permissive than the practice of the others. Therefore, the conflation of built and cultural heritage makes the correct professional interpretation difficult as well. Nowadays, during architectural monumental interventions, the problems of the professionals occur not only in technical questions like distinctness between the old and the new, or the authenticity, but even in the managing of conflict between the professional and the public's will, that is generated in many instances from cultural or political background. In fact, the monumental preservation has to face new challenges as well as sustainable development or cultural diversity.

All these problems can be evaluated through the design and construction of the Old Bridge reconstruction, and given that, help us formulate the questions.

\section{THE SOCIAL BACKGROUND - PREVENTION PATTERNS}

During the reconstruction of the Old Bridge, "preservation and reconstruction was not only a national and political imperative, but an emotional and ideological re-

\footnotetext{
${ }^{22}$ Venice Charter ICOMOS International Charter for the Conservation and Restoration of Monuments and Sites. 1964. Available at https://www.icomos.org/charters/venice_e.pdf.

${ }^{23}$ In Hungary for instance.

${ }^{24}$ Charter of Krakow 2000; Riga Charter on authenticity and historical reconstruction in relationship to cultural heritage ICCROM/Latvian National Commission for UNESCO/State Inspection for Heritage Protection of Latvia [in cooperation with: World Heritage Committee and Cultural Capital Foundation of Latvia] Riga, Latvia, 23-24 October 2000.
} 
sponse to circumstances", expressing that the: "ambition was to rebuild the city as well as the centres of other historic towns in a form which reflected their original authenticity". ${ }^{25}$ This opened a number of consultations between the UNESCO Division of Cultural Heritage, Bosnian and international experts, but also in the local population. The overall response to the question of international commitment to the Western Balkan's cultural heritage has appeared in the mid 1990s. Crucially, as a part of the global cultural heritage policy, three different patterns of action have been adopted by UNESCO, namely: prevention, integration and reconstruction. ${ }^{26}$

First, the prevention pattern refers to incorporating Balkan heritage sites into UNESCO's 'World Heritage List in Danger', pointing out armed conflicts and war as the first potential destructive threats; related national list of monuments in danger for each of the Southeastern European countries, which initially has been regarded as a solution for effective efforts to prevent war-time abuses and destruction of historic and religious monuments. Instances for this action include important sites such as the Old Bridge in Mostar.

Before the war, the Old Bridge has enjoyed particular attention as a major touristic site with significance, as a protected monument of SR Bosnia and Herzegovina, ${ }^{27}$ however not yet inscribed on the list World Heritage Sites. ${ }^{28}$ The candidature for Nomination for Inscription on The World Heritage List for The Old Bridge area of the Old City of Mostar came after the armed conflict in 1999, when ICOMOS had made a decision in 2000 to support the inscription as a special case, describing the whole project as a "positive contribution to the protection and management of this outstanding multicultural heritage sites". Hence, one selection criterion was referred to in the inscription Criterion (vi): "With the 'renaissance' of the Old Bridge and its surroundings, the symbolic power and meaning of the City of Mostar - as an exceptional and universal symbol of coexistence of communities from diverse cultural, ethnic and religious backgrounds - has been reinforced and strengthened, underlining the unlimited efforts of human solidarity for peace and powerful co-operation in the face of overwhelming catastrophes." 29

Therefore the "integration of international policies into the local capacities for change seeking to facilitate efficient institutional reforms and to create legal frameworks for the protection and restoration of cultural heritage on local level" 30 constitutes the second pattern of action. After civil wars, in decision making processes of the inner-city multi-ethnic areas destroyed in a war or armed conflict, large-scale opportunities for planning and rebuilding are offered. In his investigation into the reconstruction, Bold shows the usage of the word 'opportunity' indicating that it is "used by politicians and built environment professionals in cases, although is dif-

${ }^{25} \mathrm{~A}$. Kasten 2018. 65, referring to Warsaw.

${ }^{26}$ Kostadinova 2013. 6.

${ }^{27}$ Accordingly, all six federal republics under Socialist Federal Republic of Yugoslavia (SFRY) got a prefix "SR", for instance, SR Bosnia and Herzegovina or Socialist Republic of Bosnia and Herzegovina.

${ }^{28}$ See more in detail Jokilehto et al. 2008.

${ }^{29}$ Nomination for Inscription 2005.

${ }^{30}$ Kostadinova 2013. 6 . 
ficult concept for those who have lost family, members, friends, homes and livelihood to accept."."31

How can imported international reconciliation policies and mechanisms achieve reuniting multiethnic societies and building a sustainable peace? From which aspect is the cultural heritage in recreation of the concept of the common and shared past between different communities of Bosnia and Herzegovina seen?

Specifically, one of the prioritized factors in post-war societies is the "reconstruction of cultural heritage as part of the peace-building efforts aiming at stabilization through reversal of war effects and promotion of inner-ethnic reconciliation"32. It is through the cultural, social and economic reconstruction of communities and stimulus for the displaced to be returned to their home. Involving international assistance and International aid after an armed conflict in multi-ethnic Bosnia and Herzegovina, cultural heritage has also been prioritized in the agenda of the international organizations involved in the region; protection measures are related to the harmonized set of laws for the protection of listed national monuments. ${ }^{33}$ Consequently, "[i]f the cultural values $[\ldots]$ [could be a] principal target for destruction $[\ldots]$ then inevitably they must play a leading role in the recovery and reconstruction of society following formal end of the conflict". ${ }^{34}$ In addition, the Historical Urban Area of Mostar was listed as a national monument with boundaries that correspond to the area of the inscribed property. ${ }^{35}$

Speaking of financial donors, favoring in providing a substantial amount of financial aid to the restoration of specific religious building towards their specific ethnic group, making a politicization of the process and acquiring of national political agendas could sometimes be evident. "Every post-conflict country is unique, and no single formula can respond to all reconstruction needs. The Bank ${ }^{36}$ has used a broad array of mechanisms to support the transition to peace and the resumption of economic and social development. Its lending operations have consisted of macroeconomic and sectoral adjustment reforms, direct investment, and technical assistance in support of reconstruction." 37

The transnational aid on the post-conflict reconstruction of religious institutions has exceeded its cultural dimensions on both macro and micro political level. On a macro-political level, transnational aid tended to serve as a tool of promoting state policies through certain methods, since the conventional diplomacy has failed to

\footnotetext{
${ }^{31}$ Bold-Larkham-Pickerd 2018. 85.

${ }^{32}$ Kostadinova 2013. 5.

${ }^{33}$ Law on Implementation of Decisions of the Commission to Preserve National Monuments of Bosnia and Herzegovina (2002), the Law on the Protection and Use of Cultural, Historical and Natural Heritage of SR Bosnia and Herzegovina (1985) and the Law on Physical Planning and Land Use at the Level of Federation of Bosnia and Herzegovina (2006), accompanied by other related laws and regulations.

${ }^{34}$ Montejo 1999 Citation from Stanley-Price 2005. 3.

${ }^{35}$ Old Bridge Area of the Old City of Mostar, https://whc.unesco.org/en/list/946 (Accessed 10 January 2019)

${ }^{36} \mathrm{It}$ is referring to The International Bank for Reconstruction and Development - The World Bank.

${ }^{37}$ Kreimer et al. 2000. 3.
} 
apply. On micro-political level, it often means to mark a political presence and domination of a particular ethnic group..$^{38}$

The third pattern of action is evident in numerous cases, prioritized restoration and reconstruction of historic sites, institutions and museums damaged during the Yugoslav wars have been given primary attention, due to their key role in identity politics, as an important security factor aiming at a long-term stabilization and democratization of Balkan regions, through direct necessary accurate and massive aid. For the reason of generating and allocating funds and technical support for reconstruction of heritage from member states and private donors, UNESCO has created a World Heritage Fund and Rapid Responsive Facility. Hence, attracting numerous NGOs to enter to the Western Balkans, elaborated programs and projects for promoting cultural heritage as a way for stabilization and inter-ethnic tolerance and understanding have been commenced. An increase in the aid needed was noted with foundations launched in 1995 on intergovernmental levels, from politicians and experts. ${ }^{39}$

Under those circumstances, how can the historic and monumental values and overall significance of the city of Mostar and the Old Bridge succeed to overtake the main idea of reconciliation and that of common culture, above the politicization in reconstruction of just religious sites, since the bridge, by its character, is classified as a non-religious monument?

\section{WHY AND HOW TO RECONSTRUCT - PROS AND CONS}

The project of reconstruction of the Old Bridge can be seen in two different connotations, affirmative and dissentient. Many have looked upon it with disbelief and have been convinced that it would not be plausible to successfully recover the site according to its original appearance, and revelation, wanting to criticize the reconstruction as architectural pastiche without emotional attachment. Some have expressed enthusiasm, understanding its implied meaning. More importantly, there are two distinguished concepts: the aims on one side, seen as ideology of the preservation, and the methods on the other side, the principle by which they are operated. Those concepts are taken in order to answer the most important aspect in reconstruction: the authenticity and integrity, elaborated in the last section of this article.

The project of reconstruction of the Old City of Mostar and the Old Bridge after the destruction have become a central issue, as it was seen as one of the biggest and most complicated projects. The reconstruction of the aforementioned non-religious sites such as the Old Bridge, the politics of international aid on micro-level was ethnicized; since it was destroyed by the citizens of Mostar, not everybody shared the same feelings about the monument and about conserving the bridge. "Today Croats of Mostar do not perceive the Old Bridge as part of their own cultural history, but as

\footnotetext{
${ }^{38}$ Kostadinova 2013. 5.

${ }^{39}$ Ibid. For more details see: Chandler 2000; Khalaf 2017.
} 
evidence of increased Muslim presence in the town." ${ }^{40}$ In this respect, we must be aware that the bridge does not have religious meaning and function; "the Bridge has always been the reason of the existence of the whole town and of its population" ${ }^{41}$.

Stanley-Price ${ }^{42}$ claims "the common experience of something been valuated only after it has been lost or is threatened with destruction" has expressed the reason of the underrating of cultural heritage, and would thus be seen as unacceptable in the case of the Old Bridge, since it has gained local identity and has become a true symbol of pride and identity of the people of Mostar, not just in recent history, but through the centuries.

The final decision for rebuilding the bridge on the site has tended to focus on the expressed will of the city of Mostar and the population of Bosnia rather than keeping within, yet respecting, the limits of the charters ${ }^{43,44}$ for the conservation and restoration of monuments and sites, as a key twentieth-century doctrinal text. ${ }^{45}$

Other observations, as highlighted by one of the architects, Manfredo Romeo - as representative of the General Engineering Workgroup ${ }^{46}$ - indicate that the explanation of the charters ${ }^{47}$ is insufficient, because the population's will "is something that can not be expressed trough rules and principles and that is much stronger than any other theoretical and professional approach: it is the will and the spirit of the people that live in the place". ${ }^{48}$

Many experts contend that an alternative explanation might be that the reconstruction as a way of preservation is a tool of reanimating the society that preceded the disaster. "There is no doubt that reconstruction is a process that must go beyond mere physical reconstruction: one need to address it as a multifaceted process, as a part of larger recovery plans. It must encompass socio-economic questions within an integrated approach, prioritizing the needs and cultural rights of local communities affected by the destruction of their cultural heritage. Reconstruction must also be a tool for reconciliation, and mitigate the risks of reinventing heritage and rewriting history." ${ }^{49}$

On this aspect, Jad Tabet ${ }^{50}$ in his seminal article writes that "reconstruction was then, and indeed remain, in a process of responding 'the victims' urgent needs, to

\footnotetext{
${ }^{40}$ Kostadinova 2013. 12.

${ }^{41}$ Cited in the Interview with Manfredo Romeo.

${ }^{42}$ Stanley-Price 2005. 7.

${ }^{43}$ Referring to the Venice Charter 1964 - despite its controversial side towards reconstructions, exceptions have been made as e.g. in the case of rebuilding the historic centre of Warsaw as per the Polish people's will.

${ }^{44}$ The Athens Charter 1931 needs to be taken into account as well.

${ }^{45}$ Cited in the Interview with Manfredo Romeo.

${ }^{46}$ The final architectural and structural design for the rehabilitation of the Old Bridge in Mostar has been provided by General Engineering and the Department of Civil Engineer of the University of Florence.

${ }^{47}$ Charter of Krakow 2000, Article 4: "The reconstruction of entire parts 'in the style of the building' should be avoided. [...] Reconstruction of an entire building, destroyed by armed conflict or natural disaster, is only acceptable if there are exceptional social or cultural motives that are related to the identity of the entire com-

${ }^{48}$ Cited in the Interview with Manfredo Romeo.

${ }^{49}$ Han 2018. 44.

${ }^{50}$ Tabet 2018. 10 .
} munity." 
limit the effects of the traumas produced by the violence and to preserve the benchmarks that ensure a minimum of social cohesion." Eventually, according to him, an additional intention of reconstruction is to ensure a form of reconciliation between the parties in action. With this in mind, other experts indicate that there must be a way of allowing conflict to be regulated in terms that do not call coexistence into question. As a final point, Tabet notes that the reconstruction of the Old City of Mostar and the Old Bridge symbolized tolerance and coexistence between different religious groups, with support of the International Scientific Committee by UNESCO, which was "a symbol of reconciliation, international cooperation and the coexistence of different cultural, ethnic and religious communities".

\section{TECHNICAL BACKGROUND - METHODS \\ (THE EXACTING INVESTIGATION AND SURVEY OF THE BRIDGE, AND THE INTERVENTION)}

The reconstruction process of the Old Bridge, nonetheless, had posed a number of significant technical challenges. As mentioned by Orlando et al., "51 "the bridge shape was almost symmetrical, apart from some small irregularities due to ordinary construction errors or settlements". It could be stated that "the Old Bridge was curved, torn and literally twisted, taking into account mathematical differences ${ }^{52}$, certainly invisible to the naked eye. That is and has been a definite issue, so all of the millimeters of irregularity must have been calculated in the project of reconstruction." 53 Experts involved in the reconstruction, in accordance with the objective of the projects, turned out only one acceptable possible solution of rebuilding the bridge: "to build the same structure, and not to perform the presumed organization of a XVI century $[\ldots]$ have to respect each stone size and geometry". ${ }^{54}$

Different sides and procedures in the project of reconstruction have been developed. The theoretical reconstruction, as a base of every monumental intervention, has been based on wide preliminary studies assessed during the first phrase, focused primarily on the usage of ancient techniques and methods, original materials and reconstructing in its original shape. Considering the overall studies of the monument, drawings or pictures, and the fact that none of the originals have been found, the historical documents acquired from the preservation of the bridge in the 20th centu-

\footnotetext{
${ }^{51}$ Orlando-Spinelli-Vignoli 2003. 618.

${ }^{52}$ The primary analysis investigated the main geometric dimensions of the Old Bridge. Respectively, the north and the south side of the bridge had a span of $2871 \mathrm{~cm}$ and $2862 \mathrm{~cm}$ and an arch rise of approximately $1206 \mathrm{~cm}$. The eastern springing was about $12 \mathrm{~cm}$ lower than the western. The arch consisted of 111 rows and each row was formed by 2 to 5 voussoirs, with average dimensions of $0.40 \times 0.80 \times 1.00 \mathrm{~m}$. For further details, see: Popovac 2006. 52.

${ }_{53}$ Čolak 2013. 28.

${ }^{54}$ Cited in the Interview with M. Romeo.
} 
ry, precisely measured drawing and available photographic documentation taken before the destruction, ${ }^{55}$ defined the initial work in this project.

The data and the 'total destruction' categorization in the case of the Old Bridge showed that the partial reconstruction, which is closer to the restoration, could not be taken into account. ${ }^{56}$ The findings of the project suggested that: "at the very beginning of this assessment [he refers to project reconstruction] everybody involved in this ambitious project was thinking and hoping to have the technical possibility to rebuild the bridge following a sort of anastylosis technique". ${ }^{57}$ This technique couldn't be applied and proceeding with the project had been limited in several ways. Firstly, the investigations of the overall stone residue found in the river and near abutment walls were inadequate in amount to be repositioned in the original position, and therefore there was a possibility of greater damages to the stones and having a detrimental effect on these specimens of the antique practice of assembling. But even so, it could not be ensured that using the stones found would gain the integrity and authenticity, and it has been generalized as a "new bridge with some stone of the old one inserted as spots", which was defined as an unacceptable approach. "Other limits to the reuse of old recovered stone are their scarce quality and the difficult recognition of their original positions". ${ }^{58}$ Regarding the possibility of exploitation of the anastylosis technique, the architect Manfredo Romeo claimed that the usage of this technique would impact: "this way the integrity of the monument is preserved with its historical value, but those portitions will have a lower relevance."

Research participants in this great challenge and difficult task in the beginning of the project were raising answers to issues concerning the reconstruction, the preservation and the declared reintegration, respecting the structural requirements and safety security factors as foreseen by the European standards. After the archaeological excavations and conservation works for the rebuilding of the bridge, as well as dismantling the residual parts, a credible view of the bridge and a structure from the predecessors could be assessed.

It is a well-known phenomenon that after the aforementioned armed conflict a process of revival of cultural traditions has been commenced, often to readopt the usage of natural materials and revitalization of traditional crafts such as stone carving that become obsolete in the country. ${ }^{59}$

\footnotetext{
${ }^{55}$ The first systematic study on the evaluation and assessment of the Old Bridge in Mostar was performed in 1963, on the basis of already made technical evaluation of the Old Bridge in the years before 1952. Extensive and most important conservation works have been carried out, encompassing inspect mensuration of distinct and accessible parts of the building, regarding the scaffold. In this work, which had yielded completed and processed documentation, the vault was injected and damaged blocks were changed. (Čolak 2016; Katanic 1964; Katanic 1970.) Later on, another additional restoration work focused on reinforcing and consolidation of the bridge's foundations and river banks, and using an injection method in restoration of the supports. In 1982, archeological research and a photogrammetric survey of the bridge were conducted. The aim of those terrain investigations was to get a detailed technical analysis for the 2004 reconstruction.

${ }^{56}$ For details see Radnić et al. 2012.

${ }^{57}$ Cited in the Interview with M. Romeo.

${ }^{58}$ Orlando-Spinelli-Vignoli 2003. 620.

${ }^{59}$ Ibid.
} 
Under those circumstances, the only differences defined in the process of reconstruction from the original Old Bridge are the usage of new type of mortar, with elasticity and waterproofing characteristics, and with an exception of the visible ones, all other dowels and cramps where made of stainless steel. ${ }^{60}$

\section{THE ARCHITECTURAL “LOGIC” IN THE RECONSTRUCTION}

As we can see, the "logic" of planning and researching is not the same in this case. The evident irregularity in the geometry of the bridge shows the difficulties from the instability of the scaffold, as a result of the reducing and torsion of the new scaffold. In need to provide an adequate solution for constricting the bridge, by constructing two additional towers ${ }^{61}$ on each side of the bridge, Hayruddin made the smallest possible span for the bridge, or rather as much as the configuration of the terrain allowed. He raised the stone bridge higher, so that its wooden predecessor could be used as a scaffold and reliance for the stone bridge construction. The scaffold has been the key element for successful construction of the bridge. ${ }^{62}$

Accordingly, in the case of the reconstruction of the Old Bridge, the selection of adequate scaffolding for the heavy stone construction had been an important segment of the project, although it was not proposed in the reconstruction project. As expected, the planning logic and procedure of the new bridge in 2004 differed from the first scaffold used in 1566, which in turn demonstrates different criteria than that of the original Old Bridge (Fig. 2).

The first step in the reconstruction had been adjusting the scaffolding construction and the centering of the arch. The choice of heavy scaffolding construction, although

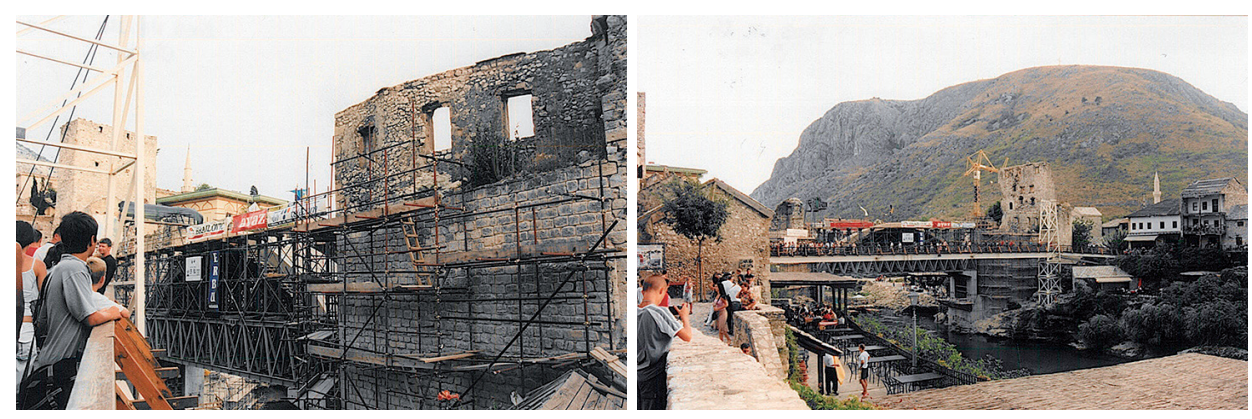

Figure 2. The Old Bridge reconstruction in 2003 (photo: Á. Gyetvai Balogh)

${ }^{60}$ Orlando-Spinelli-Vignoli 2003. 620.

${ }^{61}$ The towers built on both sides of the river Neretva, Helebija and Tara, during centuries has served as a fortification. Completed hundred years after the completion of the bridge, their construction has been started in medieval times, before the bridge was built. (Colak 2016. 153; C̆olak 2013. 27.)

${ }^{62}$ Peković 2006. 161. 
opposed to the light arch scaffolding often used in building design and construction, gave a solution to responding to all project tasks and met all conceptual requirements of the project. Therefore, the entire steel structure, up to the wooden bedding, was chosen to satisfy the weight of this kind of stone heavy bridge. ${ }^{63}$

\section{THE STEPS OF RECONSTRUCTION}

To sum up, the project reconstruction entails four specific monumental interventions according to the architect Manfredo Romeo, as an architectural design leader of the project of reconstruction.

First, conservation and preservation of ancient stones recovered from the river. All the recovered bridge stones and arch voussoirs, as he mentioned, are "the only valuable elements of a great ancient monument, they have a historic value, and they represent an interesting example of an ancient technique of assembling voussoirs and a constructive method". Clearly, this assumption is consistent with the intention to be preserved and settled in a purpose-built museum for exhibition purposes, which holds the guaranties of their safeguarding and long-lasting preservation, and conversely, rigorous towards their reuse. In addition, more reasons are given as to why the museum has been seen as a very important requirement of the project.

Subsequent studies on the surrounding area of the Old Bridge indicated important archeological findings, which reveal several traces of masonry structures assigned to the predecessors of the bridge and medieval archeological objects; the excavations, including the springer excavation as well, have opened the possibility for extensive research of the used ancient construction methods, and provided high quality restoration of the foundation walls on both sides of the bridge. The archeological researches of the most valuable remnants "have integrated and modified the image of the site development $[\ldots]$ changed the flow of the construction, and have provided more elements for precise dating of specific walls". ${ }^{64}$

Second, remedial and repair of built-in stones, bridge remnants, abutment walls and flooring. Manfredo Romeo described the process as a complex and delicate intervention, especially in the building of the arch.

In the process, besides the most used new materials, there is evidence of integration of historical material. Decomposed original pavement was maximally used to ensure the aims of making an original composition.

Third, dismantling and remounting some portions in the original locations of the bridge remnants. Study from a technical point of view supports the process of partial dismantling of the existing weak and fractured masonry remains and abutment walls of the bridge to ensure a solid base for the arch, and later, a procedure of remounting followed by a similar process of anastylosis. All the work has been made according to the detailed scientific analysis and reports.

\footnotetext{
${ }^{63}$ Popovac 2006. 54.

${ }^{64}$ Popovac 2006. 58.
} 
Finally, reconstruction of a "new Old Bridge" marked and declared as a recent intervention.

In response to the question "where is the evidence that a national or community sense of cultural identity can be dissolved by the destruction of monuments or cultural objects" proposed the architect indicates that "the imaginative identification is so powerful that the loss feels agonizing - even, perhaps, to people who never saw the object before it was ruined". Ascherson ${ }^{65}$ was giving reference to the Old Bridge as their symbol, regarding the strength of the bridge as the strength of the Bosnian people, and considering that its disappearance will change the City of Mostar and all of Bosnia and Herzegovina. Given those points, is the notion of the rebuilt bridge, in physical significance, authentic?

\section{SIGNIFICANCE AND AUTHENTICITY OF THE OLD BRIDGE}

Researching the question of the historic center of the city of Mostar as an exceptional example of cultural and historical values for human civilization, and its key feature which has been seriously damaged with enormous destruction - the Old Bridge is closely related to research into an arguably important aspect of its authenticity unified with its integrity. The attention has been drawn on "Authenticity and integrity of monument as two important criteria for the assessment of its value can be affected by the change of social climate." $" 66$

The overall project of reconstruction obtained accurate results providing that "the restoration of authenticity of the entire visual context is highly emphasized" and valuable in solving the difficulty of the authentic reconstruction. The "the reconstruction was performed using the original building techniques and methods of the construction avoiding any modernizations or alterations that would differ the structures from the original and damage the authenticity and integrity of the site." ${ }^{\circ 7}$ including any kind of adjustment of visual features of the monument or inappropriate interpretations of the documentation have been deemed unacceptable.

The project remained faithful to the original concept through usage of contemporary theories and practices, accompanied by extensive research of the documentation, other studies and reports on the indigenous structure destroyed, re-use of the original materials found on site and in overall usage in reconstruction. Taken together, it ensures the success of the attempt to recover the constructive unit that was significantly destroyed during the armed conflict, succeeding with "the authenticity of form, use of authentic materials and techniques are fully recognizable" ${ }^{68}$ The challenge in the assessment of authenticity in the recovery of the Old Bridge as a

${ }^{65}$ Ascherson 2005. 23.

${ }^{66}$ Radulovic 2015. 282.

${ }^{67}$ Op. cit. 286.

${ }^{68}$ Op. cit. 288, reference given to UNESCO 2005, Advisory Body Evaluation, Mostar (Bosnia and Herzegovina) No 946 rev., p. 181. 
masterpiece of Ottoman architecture is related to an original substance: an intervention that consists of very high percentage of reconstructed (new built) parts and very high percentage of usage of new materials. ${ }^{69}$ The choice of highly traditional materials and stone cutting, lead pouring procedure was to consider its technical, aesthetic and ethical advantages. ${ }^{70}$

Speaking of the development of Mostar during the Ottoman era is a representation of "the connection between the landscape and men-constructed elements established on a multicultural setting, typical for this region", with visible style influence from different periods. The unique integrity of the Old City of Mostar as an authentic urban compound with its architecture has been damaged by losing the key monument - the Old Bridge. As a "part of a very specific ensemble that was one of the most beautiful and most unique in Europe, important for Balkan-Mediterranean visual scope and history, additionally it had a functional value for local people". ${ }^{71}$

Authenticity on the urban scale has been indicated as being "preserved through an integrative rehabilitation of the historic core by the renovation of physical structures and the introduction of the appropriate functions."72. What is more, positioning and preserving the typology and morphology of the historic fabric and the objects by reconstruction considered through an original volume, sites and construction material of each structure in the natural and urban landscape, is one of the most positive achievements of this project. On the other hand, the Old Bridge with the sense of identity demonstrates the embodiment of memory and history, its adjustment into the setting of natural surroundings and its urban matrix, and it is evident that the city possesses irreplaceable cultural and historical values, which have proven to be the most difficult matter of reconstruction. "Positioning of the ensemble in the natural and urban landscape is one of the most positive achievements of this project." 73

Despite the persuasive arguments of the reconstruction method chosen in the recovery, it plays a particular role in the renewal of an authentic cultural identity of the town and region, which is an important function not only in a restoration of (tangible) aspects, but also a major role in the reconciliation process and imagining of the sustainable peace, by encouraging the close contact of the citizens of Mostar in the overall reconstruction work, in order to resurrect the feelings related to the pre-conflict significance that the bridge held for the local residents.

After all, A. Karsten ${ }^{74}$ states that "Concerning buildings, authentic form and the original substance are their most important attributes. Unfortunately, these cannot be preserved unchanged for ever - even in peacetime - since the ageing process and alterations to the functional arrangements of buildings will both impact upon the authenticity of the original object." 75

\footnotetext{
${ }^{69}$ Radulovic 2015. 286.

${ }^{70}$ For details, see: Nara Document 1994.

${ }^{71}$ Radulovic 2015. 286.

${ }^{72}$ Nomination for Inscription 2005, https://whc.unesco.org/en/list/946.

${ }^{73}$ Radulovic 2015. 286.

${ }^{74}$ A. Karsten 2018.

${ }^{75}$ Op. cit. 64.
} 


\section{CONCLUSION}

This article set out to examine the under-researched professional, social and political questions in architectural reconstruction by the example of the Old Bridge in Mostar. We have aimed to improve our understanding of the judgement of the architectural reconstruction or rebuilding and the prosperity of the recovery indicating the authenticity question. We identify that the examination of the Old Bridge's rebuilding raises even deeper theoretical questions. Every monumental intervention, like reconstruction, is a contemporary architectural act, where the theoretical reconstruction is fundamental. However, the "architectural logic" that we use by decoding the original planning method through the theoretical reconstruction more or less differs from the factual architectural reconstruction work's logic that we are using nowadays. In rebuilding this two type of logic is closer to each other than in any other monumental intervention mode. So the chosen architectural "language" or architectural approach of the reconstruction is based on finding original forms and materials. For that reason, the ultimate goal can be achieved only by completion of the ruined monument. Every other solution is "illogical". In the case of a full reconstruction the architectural approach is the mimetic or assimilated way that tries to conjure the original appearance.

In every monumental intervention, the relation between the old remains and the new or implanted parts is of exceptional importance. It can be tested or evaluated in the following: the justification of new parts (or the professional base behind the planning); the subordinate or juxtaposed relationship between the remains and new parts (which is of grave importance); the lucidity/interpretability of the intervention (in other words, what the public can understand from the architectural signals); the question of reversibility; and as described above the selected architectural approach (also known as the architectural language of the intervention: dissonance, assimilation, or the dialectic contact.) All of these aspects cannot be evaluated in the case of rebuilding, where we may impose: can reconstruction be interpretable as a monumental intervention?

The authenticity in the case of architectural reconstruction is controversial as well. How can we measure the level of authenticity in a case of reconstruction? Which component of authenticity should be studied? We cannot use historical methods and materials in contemporary buildings without modifications, which would conclusively lead to falsifications. The time period between destruction and rebuilding is essential from the professional and practical point of view, which can in turn bring up not only architectural or theoretical but even ethical questions.

In the case of the Old Bridge we can see the effect of the social and political background on the professional decision-making. In post-war situations, the questions have become more practical rather than theoretical. In these cases, the social background is superior than the theoretical, but the question always remains: What will be the rule of the contemporary reconstructions regarding the future? Can the com- 
pletion of the reconstruction serve as a permanent solution and conclusion of the past or will it serve solely as a new layer on the monument's history, until something more advanced appears as a new prevailing solution?

\section{BIBLIOGRAPHY}

A. Karsten 2018

Ascherson 2005

Athens Charter 1931

Barakat 2005

Bold 2018

Cameron 2017

Čolak 2013

Colak 2016

Čelić-Mujezinović 1998

Brosché et al. 2016
Appelbom Karsten, Ingrid: Reconstruction of Historic Monuments in Poland after the Second World War - The Case of Warsaw. In John Bold - Peter Larkham - Robert Pickerd (eds): Authentic Reconstruction, Authenticity, Architecture and the Built Heritage. Bloomsbury Academic, London 2018. 47-68.

Ascherson, Neal: Cultural Destruction by War and Its Impact on Group Identities. In Nicholas Stanley-Price (ed.): Cultural Heritage in Postwar Recovery. Papers from the ICCROM FORUM held on October 4-6, 2005. ICCROM Conservation Studies 6, ICCROM, Rome 17-25.

The Athens Charter for the Restoration of Historic Monuments - 1931. ICOMOS. Available at http://www.icomos.org/en/charters-and-texts/ 179-articles-en-francais/ressources/charters-and-standards/167-theathens-charter-for-the-restoration-of-historic-monuments (Accessed 10 January 2019)

Barakat, Sultan: Postwar Reconstruction and the Recovery of Cultural Heritage: Critical Lessons from the Last Fifteen Years. In Nicholas StanleyPrice (ed.): Cultural Heritage in Postwar Recovery. Papers from the ICCROM FORUM held on October 4-6, 2005. ICCROM Conservation Studies 6, ICCROM, Rome 26-40.

Bold, John: Introduction: Reconstruction: The Built Heritage Following War and Natural Disaster. In John Bold - Peter Larkham - Robert Pickerd (eds): Authentic Reconstruction, Authenticity, Architecture and the Built Heritage. Bloomsbury Academic, London 2018. 1-25.

Bold-Larkham-Pickerd 2018 Bold, John - Larkham, Peter - Pickerd, Robert (eds): Authentic Reconstruction, Authenticity, Architecture and the Built Heritage. Bloomsbury Academic, London 2018.

Brosché, Johan - Legnér, Mattias - Kreutz, Joakim - Ijla, Akram: Heritage under Attack: Motives for Targeting Cultural Property during Armed Conflict. International Journal of Heritage Studies 23 (2017) 3. 248-260. DOI: 10.1080/13527258.2016.1261918 Available at https://www.pcr.uu.se/ digitalAssets/.../348208_1brosch--et-al--2016 (Accessed 4 January 2019)

Cameron, Christina: Reconstruction: Changing Attitudes. The UNESCO Courier 2 (2017) 56-59. Available at https://en.unesco.org/courier/julyseptember-2017/reconstruction-changing-attitudes (Accessed 4 January 2019)

Čolak, Ivo: Kratki prikaz revitalizacije lokaliteta starog mosta. e-Zbonik: Electronic collection of papers of the Faculty of Civil Engineering 5 (2013) 24-32.

Colak, Ivo: The Reconstruction of the Old Bridge in Mostar. In B. Katalinic (ed.): Chapter 14 in DAAAM International Scientific Book 2016. DAAAM International, Vienna 2016. 151-162. DOI: 10.2507/daaam.scibook.2016.14 Čelić, Džemal - Mujezinović, Mehmed: Stari mostovi u Bosni i Hercegovini. Sarajevo Publishing, 1998. 
Chandler 2000

Charter of Krakow 2000

General Engineering Work Group Stari Most. Rehabilitation Design of the Old Bridge in Mostar. Available at http://www.mostarbridge.org/starimost/00_main/team/team obj.htm (Accessed 10 January 2019)

Hadzimuhamedovic 2018 Hadzimuhamedovic, Amra: Reconstruction of the Old Bridge in Mostar World Heritage 86 (2018) 20-26. Available at https://unesdoc.unesco.org/ ark:/48223/pf0000261514 (Accessed 10 January 2019)

Han 2018

Interview with $\mathrm{M}$. Romeo

Jokilehto 2006

Jokilehto et al. 2008

Katanic 1964

Katanic 1970

Khalaf 2017

Kostadinova 2013

Kreimer et al. 2000

Nara Document 1994 https://www.icomos.org/charters/nara-e.pdf (Accessed 10 January 2019)

Han, Junhi: The Bamiyan Buddhas: Issues of Reconstruction. World Heritage 86 (2018) 41-45. Available at https://unesdoc.unesco.org/ ark:/48223/pf0000261514 (Accessed 10 January 2019)

General Engineering Introduces the Architectural Design of Arch. Manfredo Romeo (Architectural Design Leader) - General Engineering Workgroup. Available at http://www.mostarbridge.org/starimost/00_main/interview/ interview.htm (Accessed 10 January 2019)

Jokilehto, Jukka: Considerations on Authenticity and Integrity in World Heritage Context. City \& Time 2 (2006) 1. 1. Available at http://www.ct. ceci-br.org (Accessed 10 January 2019)

Jokilehto, Jukka - Cameron, Christina - Parent, Michel - Petzet, Michael: The World Heritage List. What is OUV? Defining the Outstanding Universal Value of Cultural World Heritage Properties. Hendrik Bässler Verlag, Berlin 2008.

Katanic, Nadezda: Nastavak ispitavanje I proucavanje starih kamenih mostova u Hrvatskoj, Sloveniji i Hercegovini. Zbornik zastite spomenika culture (1964) 15. 105-114.

Katanic, Nadezda: Ispitavanje I proucavanje starih kamenih mostova I akvadukta u Jugoslaviji. Zbornik zastite spomenika culture (1970/71) 20/21. 93-98.

Khalaf, Roha W.: A Viewpoint on the Reconstruction of Destroyed UNESCO Cultural World Heritage Sites. International Journal of Heritage Studies 23 (2017) 3. 261-274, DOI: 10.1080/13527258.2016.1269239

Kostadinova, Tonka: International Aid to the Reconstruction of Cultural Heritage in Southeast Europe: A Peace-building Model? Jean Monnet Papers on Political Economy 2 (2013) 1-20. Available at https:// jmonneteuldcs.files.wordpress.com/2013/11/kostadinova.pdf (Accessed 10 January 2019)

Kreimer, Alcira - Muscat, Robert - Elwan Ann - Arnold, Margaret: Bosnia and Herzegovina: Post-Conflict Reconstruction, Country Case Study Series. The World Bank, Washington (D.C.) 2000.

ICOMOS 1994: The Nara Document on Authenticity (1994). Available at

Nomination for Inscription 2005 Nomination for Inscription on the World Heritage List $\left(15^{\text {th }}\right.$ July 2005). The Old Bridge Area of the Old City of Mostar. Excerpt from the Decisions of the $29^{\text {th }}$ Session of the World Heritage Committee, January 2005. Available at https://whc.unesco.org/uploads/nominations/946rev.pdf (Accessed 10 January 2019) 
Orlando-Spinelli-Vignoli 2003 Orlando, M. - Spinelli, P. - Vignoli, A.: Structural Analysis for the Reconstruction Design of the Old Bridge of Mostar. Structural Studies, Repairs, and Maintenance of Heritage Architecture VIII, Edr Brebbia,

Peković 2006 WIT-Press (2003) 66. 617-626. DOI 10.2495/STR030601

Popovac 2006 Peković, Željko: Reconstructing the Original Scaffold Used in Building Stari Most (Old Bridge) in Mostar. Prostor 14 (2006) 2 (32), 158-165. Available at http://www.academia.edu/28738002/Reconstructing the Original_Scafold_Used_in_Building_Stari_most_Old_Bridge_in_Mostar_ Prijedlog_rekonstrukcije_izvorne_skele_Starog_mosta_u_Mostaru (Accessed 10 January 2019)

Popovac, Maja: Reconstruction of the Old Bridge of Mostar. Acta Polytechnica 46 (2006) 2. 50-59. Czech Technical University Publishing House, Prague 2006. Available at https://ojs.cvut.cz/ojs/index.php/ap/article/ download/824/656 (Accessed 10 January 2019)

Popovac 2011 Popovac, Maja: Materials and Techniques in Old Bridge of Mostar Reconstruction. Paper presented at the Proceedings of the $15^{\text {th }}$ International Research/Expert Conference "Trends in the Development of Machinery and Associated Technology", TMT Prague, 2011. 149-152.

Radnić et al. 2012

Radnić, Jure - Harapin, Alen - Smilović, Marija - Grgić, Nikola - Glibić, Mladen: Statička i dinamička analiza starog kamenog mosta u Mostaru. GRAĐEVINAR 64 (2012) 8. 655-665. Available at https://hrcak.srce.hr/ file/128605 (Accessed 10 January 2019)

Radulovic 2015

Radulovic, Aleksandar: The Question of Authenticity in Recoveries in Post-conflict Zones. In: Proceedings of the II International Conference on Best Practices in World Heritage: People and Communities (2015) 280296. Available at https://eprints.ucm.es/34899/1/ActasMenorca15.pdf (Accessed 10 January 2019)

Roller 1992-1993

Stanley-Price 2005 ban. Épités- Épitészettudomány 23 (1992-1993) 3-4. 309-320.

Stanley-Price, Nicholas: The Thread of Continuity: Cultural Heritage in Post-war Recovery. In Nicholas Stanley-Price (ed.): Cultural Heritage in Postwar Recovery. Papers from the ICCROM FORUM held on October 4-6, 2005. ICCROM Conservation Studies 6, ICCROM, Rome 1-16.

Tabet 2018

UNESCO 2005

Tabet, Jad: Reconstruction in the Age of Globalization. World Heritage 86 (2018) 8-14. Available at https://unesdoc.unesco.org/ark:/48223/ pf0000261514 (Accessed 10 January 2019)

Advisory Body evaluation, Mostar (Bosnia and Herzegovina) No 946 rev. (2005) 181. Available at https://whc.unesco.org/document/154662 (Accessed 10 January 2019)

UNESCO 2012 The Operational Guidelines for the Implementation of the World Heritage Convention. Available at https://whc.unesco.org/archive/opguide12-en.pdf (Accessed 10 January 2019)

Venice Charter $1964 \quad$ Venice Charter ICOMOS International Charter for the Conservation and Restoration of Monuments and Sites. 1964. Available at https://www.icomos.org/charters/venice_e.pdf (Accessed 10 January 2019)

Žderić-Radić-Kindij 2007 Žderić, Ž. - Radić, J. - Kindij, A.: Mostar Old Bridge Rehabilitation. Proceedings of ARCH'07 - the $5^{\text {th }}$ International Conference on Arch Bridges 12-14 September 2007. 695-703. Available at www.hms.civil. uminho.pt/events/arch2007/709_718.pdf (Accessed 10 January 2019) 


\title{
AZ ÉPÍTÉSZETI REKONSTRUKCIÓ „MÁSIK OLDALA”
}

\section{SZAKMAI, TÁRSADALMI ÉS POLITIKAI SZEMPONTOK VIZSGÁLATA A MOSTARI ÖREG HÍD PÉLDÁJA KAPCSÁN}

\author{
Összefoglaló
}

Az egykori Jugoszlávia területén, a fegyveres konfliktusok utáni építészeti rekonstrukciókat részletesebben vizsgálva a mostari Öreg híd (Stari Most) példáján szeretnénk bemutatni a rekonstrukciók ,,másik oldalát”; avagy mindazt, ami a szakmai oldal mellett meghatározó ezekben a helyreállítási munkákban: a társadalmi és a politikai szempontokat. Mindehhez részletesebben elemezzük a bosznia-hercegovinai kulturális örökség polgárháború utáni kezelési megközelítéseit, a nemzetközi és hazai szakértők különböző véleményeinek tükrében. Vizsgáljuk többek közt az egyre szaporodó helyreállítások hitelességre gyakorolt hatását: „vajon mennyire lehet egy eredeti élményt, tapasztalatot újjáéleszteni az elpusztult eredeti emlék szimulációjával?"

Az Öreg híd rekonstrukciójának folyamatát és egyes részleteit „az eredeti szellemben történő” helyreállitásként értékeljük, megvizsgálva szerkezeti adottságait, eredeti formájában és méretében való újjáépítését, valamint korabeli dokumentumokra támaszkodva az eredeti anyagok és technológiák használatát. Az építészeti rekonstrukciók vagy újjáépítések megitélése több szempont alapján lehetséges: a materiális és immateriális értékek hierarchiájának helyes megállapításában. A helyreállítás politikai és gazdasági okokra visszavezethető közel egy évtizedes elhúzódása számos további problémát vetett fel a hely és a formák eredetiségével kapcsolatban egy olyan környezetben, amelynek történelme máshogy alakult. Ez a megközelítés etikai és erkölcsi kérdéseket is elötérbe hozott.

Az építészeti rekonstrukció megközelítése és megítélése az egykori Jugoszlávia köztársaságaiban is eltérő a legutóbbi fegyveres konfliktusok után. Látva a társadalmi és politikai háttér sokszínüségét, felvetül a kérdés, hogy vajon a rekonstrukció csak egy újabb réteg a müemlék „stratigráfiájában” vagy a múlt végső lezárása?

Kulcsszavak: építészeti rekonstrukció, mostari Öreg híd, fegyveres konfliktusok, hitelesség, kulturális örökség

Open Acces statement. This is an open-access article distributed under the terms of the Creative Commons Attribution 4.0 International License (https://creativecommons.org/licenses/by/4.0/), which permits unrestricted use, distribution, and reproduction in any medium, provided the original author and source are credited, a link to the CC License is provided, and changes - if any - are indicated. (SID_1)

$\square$ Received: 7 February 2019. Accepted: 13 March 2019

First published online: 9 July 2019. 